\title{
BIOMONITORING OF WATER QUALITY OF RIVER NERODIME BASED ON PHYSICOCHEMICAL PARAMETERS AND MACROINVERTEBRATES
}

\author{
P.S. Bytyçi ${ }^{1,2}$, F. N. Zhushi Etemi ${ }^{2 *}$, M.A.Ismaili ${ }^{1}$, Sh.A.Shala ${ }^{3}$, \\ M.S.Serbinovski ${ }^{1}$, H.S. Çadraku ${ }^{3}$ and O.B. Fetoshi ${ }^{4}$ \\ ${ }^{1}$ Faculty of Contemporary Sciences and Technologies, South East European University, 1200, \\ Tetovo, Macedonia \\ ${ }^{2}$ Faculty of Mathematics and Natural Sciences, University of Prishtina, 10000, Pristina, Kosovo \\ ${ }^{3}$ Faculty of Engineering Energy, University for Business and Technology, \\ 10000, Pristina Kosovo \\ ${ }^{4}$ Faculty of Tourism and Environment, University of Applied Sciences, 70000, Ferizaj, Kosovo \\ *E-mail : ferdijezhushi2010@gmail.com
}

\begin{abstract}
We used physicochemical and biological parameters to evaluate the water quality in river Nerodime in Kosovo. The research was conducted in spring 2017, in three stations along the river (upstream, middle and downstream). River Nerodime is the biggest tributary of the River Lepenci Basin that flows in South Eastern part of Kosovo. During its flow, Nerodime enters the cities of Ferizaj and Kaçaniku where it becomes a collector of many pollutants of diverse origin. Our research concluded that the river conditions are very severe in middle and downstream of the river. The values of physicochemical parameters and biotic indices indicate that the water quality in the upper flow is classified good to moderate, whereas in middle and downflow, due to the discharge of municipal wastewaters, industry and agricultural runoff, the water quality significantly decreases and is poor, respectively bad quality.

Keywords: River Nerodime, physicochemical parameters, pollution, macroinvertebrates, water quality.
\end{abstract}

(c) RASĀYAN. All rights reserved

\section{INTRODUCTION}

Due to increased urbanization, industrialization, agriculture and other anthropogenic activities, water is becoming highly polluted with different harmful contaminants. High levels of organic and industrial pollutants in river water cause changes in many physicochemical parameters such as: temperature, total suspended solids, Biological oxygen demand, Chemical oxygen demand, $\mathrm{pH}$, etc. The presence of pollutants in the rivers has impacted the water quality in a level that in such cases it cannot be used for drinking, irrigation or recreation.

The importance of biological parameters as indications of the health of the river is highlighted in the European water Framework Directive ${ }^{1}$. Among the biological quality elements, the macro invertebrates are by far the most frequently used group for bio indication in standard water management ${ }^{2-5}$.

Macroinvertebrates are organisms that form an integral part of an aquatic environment and have ecological and economic importance. They are ubiquitous and abundant throughout the whole river system in the crenal and rhitral as well as the potamal part ${ }^{6}$. These are bottom dwelling invertebrates that are visible without a microscope. Like many other organisms, macroinvertebrates are sensitive to changes in $\mathrm{pH}$, dissolved oxygen, temperature, salinity, turbidity and water chemistry. Macro invertebrates act as biological indicators because they react quickly to changes in water quality conditions. Some of them are sensitive; some are semi tolerant or tolerant to different pollutants. Thus, macroinvertebrate species should reflect deleterious events that have occurred in the aquatic environment during any stage of their development ${ }^{7}$. Biomonitoring of rivers in Kosovo has a short tradition, comparing to western countries. Although macroinvertebrates are used for already 30 years in water quality assessment by researchers at

Rasayan J. Chem., 11(2), 554 - 568(2018)

http://dx.doi.org/10.31788/RJC.2018.1122087 
the University of Prishtina, biological quality elements were, until recently, neglected by responsible authorities for water Monitoring and management. With the introduction of European Water Framework Directive (WFD, 2000) biological quality elements, together with chemical elements, became essential and mandatory in water monitoring in Kosovo. According to literature ${ }^{-}$metrics (or indices) allow the investigator to use meaningful indicator attributes in assessing the status of assemblages and communities in response to perturbation ${ }^{8}$.

For a metric to be useful, it must have the following technical attributes:

1. Ecologically relevant to the biological assemblage or community under study and to the specified program objectives

2. Sensitive to stressors and provides a response that can be discriminated from natural variation.

In previous studies in Kosovo, macroinvertebrate data were mostly used to calculate Saprobic index to evaluate the level of organic pollution in aquatic ecosystems. ${ }^{9-14}$ Later on, the Biotic index (BI) and Family Biotic Index (FBI) were the most used indices for macroinvertebrates. Biological Monitoring Working Party (BMWP) and Average Score per Taxon (ASPT) have not been applied in water quality biomonitoring in Kosovo so far. Thus, this is the first time we use BMWP and ASPT to determine the water quality for a river ${ }^{15}$.

BMWP assigns scores to each macroinvertebrate taxa according to their sensitivity caused by organic pollution. The analysis of these pollution-induced responses allows the calculation of sensitivity values by the different groups of organisms. Values greater than 100 are associated with clean streams; while the scores of heavily polluted streams are less than $10 .{ }^{16}$ The average sensitivity of the families of the organisms present is known as ASPT and can be determined by dividing the BMWP score by the number of taxa present. A high ASPT score is considered indicative of a clean site containing large numbers of high scoring taxa ${ }^{17}$.

River Nerodime is the left tributary of the River Lepenci basin, which flows to river Vardar in Macedonia and belongs to the Aegean Sea drainage basin. It is the main river in the municipality of Ferizaj. River Nerodime originates on the eastern side of Mountain Jezerci ( $\mathrm{N} 42^{\circ} 22^{\prime} 09^{\prime \prime}$ E $\left.21^{\circ} 04^{\prime} 48^{\prime \prime}\right)$ at an altitude of $660 \mathrm{~m}$ asl. The length of the river is $41 \mathrm{~km}^{2}$ and reaches $228 \mathrm{~km}^{2}$ catchment area. The riverbed width is 2$5 \mathrm{~m}$, and water flows with an average speed of $0.9 \mathrm{~m}^{3} / \mathrm{sec}$. In its middle flow river, Nerodime enters the city of Ferizaj where it becomes a collector of many pollution substances from municipal wastewaters, agriculture, industry and other sources. Downstream Nerodime flows in the city of Kaçanik, which further influences the water quality by diverse anthropogenic activities.

\section{Material and Methods}

\section{EXPERIMENTAL}

Water samples for physicochemical parameter analyses and macroinvertebrates were taken in three stations (SP1, SP2 and SP3) along the course of the river Nerodime, in spring 2017. The first station is in Mountain Jezerci ( $\mathrm{N} 42^{\circ} 21^{\prime} 0^{\prime \prime} \mathrm{E} 21^{0} 1^{\prime} 8^{\prime \prime}$ ), about $1 \mathrm{~km}$ from the source. The substrate consists of big rocks in the middle and with smaller rocks and gravel aside the river bed. River morphology in this part is natural, with no modification and with minimum anthropogenic impact, although during the summer this area is frequented by many visitors. Les than one $\mathrm{km}$ downstream is a trout farm and a restaurant, which discharges wastes in the river. The second station is in village Gerlicë (N 42 $31^{\prime} 14^{\prime \prime} \mathrm{E} 21^{0} 20^{\prime} 38^{\prime \prime}$ ) on the exit from the city of Ferizaj. The water in this station arrives after many pollution sources were discharged on it in the city of Ferizaj and in rural areas where main population activity is agriculture and farming. The bottom of the river consists of rocks, sand and gravel. The third station is in Runjevë (N $42^{\circ} 24^{\prime} 45^{\prime \prime} \quad$ E $21^{0} 25^{\prime} 15^{\prime \prime}$ ), few kilometers before Nerodime joins the river Lepenci.The structure of this station also consists of large stones in the middle of the riverbed and sand and silt aside. It should be mentioned that the water in this station had bed smell and dark color during the entire time of the research.

Depending on the river depth, the organisms were collected with the D frame net or with Surber net with mesh holes of up to $500 \mu$, using multihabitat technics. The collected samples in the field were preserved in $75 \%$ alcohol and were transported in the laboratory at the Department of Biology where 
they were separated and identified with the help of a microscope and are classified to the family level using adequate $\mathrm{keys}^{18}$. The composition of benthic macroinvertebrates was analyzed to determine the diversity and Biotic indices. Three diversity indices: Shannon-Wiener $(\mathrm{H})$, Margalef $(\mathrm{DMg})$ and Menhinick index as well as six biotic indices including Taxa Richness (TR); EPT (Ephemeroptera Plecoptera Trichoptera), Biological Monitoring Working Party (BMWP), Average Score per Taxon (ASPT), SWRC (Stroud Water Research Center)-Biotic index and Family Biotic Index (FBI), were calculated to assess the water quality of river Nerodime.The water sampling for physicochemical analysis is performed by using equipment and container based on the ISO 5667-6 standard. $1 \mathrm{~L}$ sample bottles were labeled with the date and source of sampling; they were kept in refrigerators at $4{ }^{\circ} \mathrm{C}$ and transported under the appropriate procedure.

Analysis of water samples taken in the river Nerodime is performed in the laboratory of the Kosovo Hydrometeorological Institute. Water quality parameters are determined by using the following measuring equipment: WTW 350i for temperature and electrical conductivity, AQUALITIC / PC COMPACT for turbidity, $\mathrm{pH}$ measurement values are made with $\mathrm{pH}$ - meter $\mathrm{HI}$ 98130, dissolved oxygen was determined with HI 9146, BOD5, COD, total suspended matter, nitrates, detergents with spectrophotometers SECOMAN type model Pastel UV and total phosphorus with SECOMAN PRIM LIGHT.

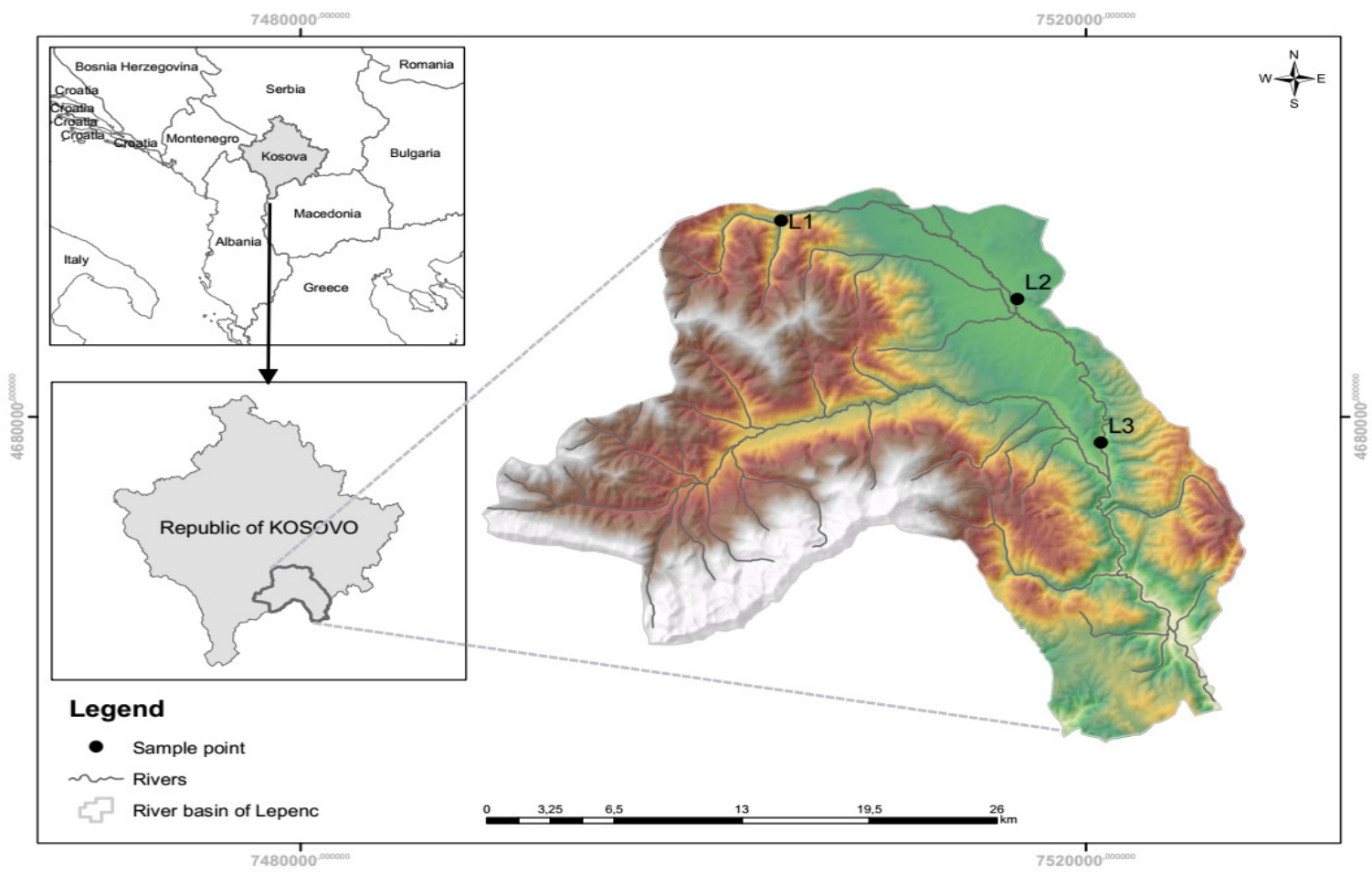

Fig.-1: Location of investigated area

\section{Physicochemical Parameters}

\section{RESULTS AND DISCUSSION}

The values of measured physicochemical parameters varied from station to station. The mean values of the physical and chemical water quality parameters at the sampling stations are summarized in Table- 1 .

\section{Temperature}

Temperature is one of the main parameters of water, which affects the development of chemical processes in water ${ }^{19}$. It varies from 0 to $100{ }^{\circ} \mathrm{C}$, and depends on many factors. It affects the amount of dissolved oxygen, water biota activity, and the speed of many chemical reactions in water. Based on the results obtained from three measuring stations in the Nerodime River, the water temperature values varied from 
$9.1{ }^{\circ} \mathrm{C}$ to $12.4{ }^{\circ} \mathrm{C}$, at SP2-Gërlicë station and SP1-Jezerc station respectively, the average value is 10.4 ${ }^{\circ} \mathrm{C}$. The water temperature in this river indicates a downward trend at the stream bottom. Temperature variation and other statistical indicators are shown in Fig.-2.

Table-1: The Values of Physical and Chemical Parameters of Water

\begin{tabular}{l|c|c|c|c|c}
\hline Parameters & \multirow{2}{*}{ Symbol } & \multirow{2}{*}{ Measure } & \multicolumn{3}{|c}{ Stations } \\
\cline { 4 - 6 } & & & $\mathrm{SP} 1$ & $\mathrm{SP} 2$ & $\mathrm{SP} 3$ \\
\hline Water temperature & $\mathrm{T}$ & ${ }^{0} \mathrm{C}$ & 12.4 & 9.1 & 9.7 \\
\hline Electro conductivity & $\mathrm{X}$ & $\mu \mathrm{Scm}-1$ & 123.7 & 411 & 356 \\
\hline Total suspended solid & $\mathrm{TSS}$ & $\mathrm{mg} / \mathrm{L}$ & 62.3 & 123 & 205 \\
\hline $\mathrm{pH}$ & $\mathrm{pH}$ & $0-14$ & 8.4 & 8.0 & 8.3 \\
\hline Dissolved oxygen & $\mathrm{DO}$ & $\mathrm{mg} / \mathrm{L}$ & 9.2 & 7.81 & 8.8 \\
\hline Saturation with oxygen & & $\%$ & 94.8 & 73.1 & 84.5 \\
\hline Chemical Oxygen Demand & $\mathrm{COD}$ & $\mathrm{mg} / \mathrm{L}$ & 4.9 & 35.0 & 42.5 \\
\hline Biochemical Oxygen Demand & $\mathrm{BOD}$ & $\mathrm{mg} / \mathrm{L}$ & 2.3 & 16.0 & 19.0 \\
\hline Total organic Carbon & $\mathrm{TOC}$ & $\mathrm{mg} / \mathrm{L}$ & 1.5 & 5.0 & 6.0 \\
\hline Nitrates & $\mathrm{NO}_{3}$ & $\mathrm{mg} / \mathrm{L}$ & 0.15 & 2.1 & 4.8 \\
\hline TP & $\mathrm{P}$ & $\mathrm{mg} / \mathrm{L}$ & 0.274 & 0.069 & 0.097 \\
\hline Phosphate ion & $\mathrm{PO}_{4}{ }^{3-}$ & $\mathrm{mg} / \mathrm{L}$ & $<0.02$ & 0.5 & 0.05 \\
\hline Detergents & $\mathrm{DET}^{2}$ & $\mathrm{mg} / \mathrm{L}$ & 0.15 & $<0.1$ & $<0.1$ \\
\hline Ammonia & $\mathrm{NH}_{4}{ }^{+}$ & $\mathrm{mg} / \mathrm{L}$ & 0.017 & 5.84 & 6.90 \\
\hline Nitrites & $\mathrm{NO}_{2}{ }^{-}$ & $\mathrm{mg} / \mathrm{L}$ & $<0.01$ & 0.091 & 0.381 \\
\hline Sulfates & $\mathrm{SO}_{4}{ }^{-2}$ & $\mathrm{mg} / \mathrm{L}$ & 3 & 8 & 11 \\
\hline Chlorides & $\mathrm{Cl}^{-}$ & $\mathrm{mg} / \mathrm{L}$ & 2.84 & 5.68 & 9.94 \\
\hline
\end{tabular}

For the purpose of interpreting and comparing this paper, Romanian standard for assessing the ecological status of surface waters of 2000 (GD 161) has been used. Therefore, referring to this standard, the temperature parameter is not defined. However, if we refer to the Albanian drinking water quality standards(STASH 3904-1998), the acceptable temperature range is from 8 to $15^{\circ} \mathrm{C}$. Based on this, the water in these watercourses is within the normative benchmarks in view of the temperature parameter.

\section{Electrical Conductivity $\chi\left[\mu \mathrm{S} / \mathrm{cm}^{-1}\right]$}

In principle, water conductivity shows an upward trend in dry seasons with low rainfall. The change in electrical conductivity of the water at a constant temperature is closely related to the change of water mineralization. It is an important indicator to hydrogeological research. The values of this indicator (parameter) in the water of Nerodime River show a variation as in Fig.-3. The lowest (minimum) value was obtained at the measuring station SP1 Jezerc $\left(123.7 \mu \mathrm{S} / \mathrm{cm}^{-1}\right)$, whereas the maximum value was obtained at the measuring station SP3 Runjevë $\left(411 \mu \mathrm{S} / \mathrm{cm}^{-1}\right)$, the average value being $296.9\left(\mu \mathrm{S} / \mathrm{cm}^{-1}\right)$.

\section{Total Suspended Solids TTS [mg/l]}

The TSS parameter values varied from $62.3 \mathrm{mg} / \mathrm{l}$ to $205 \mathrm{mg} / \mathrm{l}$. The minimum value of $62.3 \mathrm{mg} / \mathrm{l}$ was obtained at Jezerc SP1 station, the maximum value of $205 \mathrm{mg} / \mathrm{l}$ was obtained at the measuring station SP3 Runjevë, the average TSS value being $130.1 \mathrm{mg} / \mathrm{l}$. The variation of TSS parameter is shown in Fig.-4.

\section{The Concentration of Hydrogen Ions (pH)}

The average value measured at three stations in Nerodime River indicates that the water is alkaline. $\mathrm{pH}$ values are presented with small variations (a minimum value of 8 and a maximum value of 8.4, the average value being 8.2, as seen from the respective values of DS and $\mathrm{Cv}$. This narrow variation of $\mathrm{pH}$ values indicates that there is no significant impact of civil and industrial discharges in the monitored 
surface water flow. The $\mathrm{pH}$ values monitored in the water of Nerodime River have been compared with the respective values of the Romanian standard for assessing the ecological status of the surface waters of 2006 (GD161). Based on this comparison, it has resulted that the measured pH values in the water of Nerodime River lie in the normal range at all three measuring stations. The $\mathrm{pH}$ value variation is shown in Fig.-5.

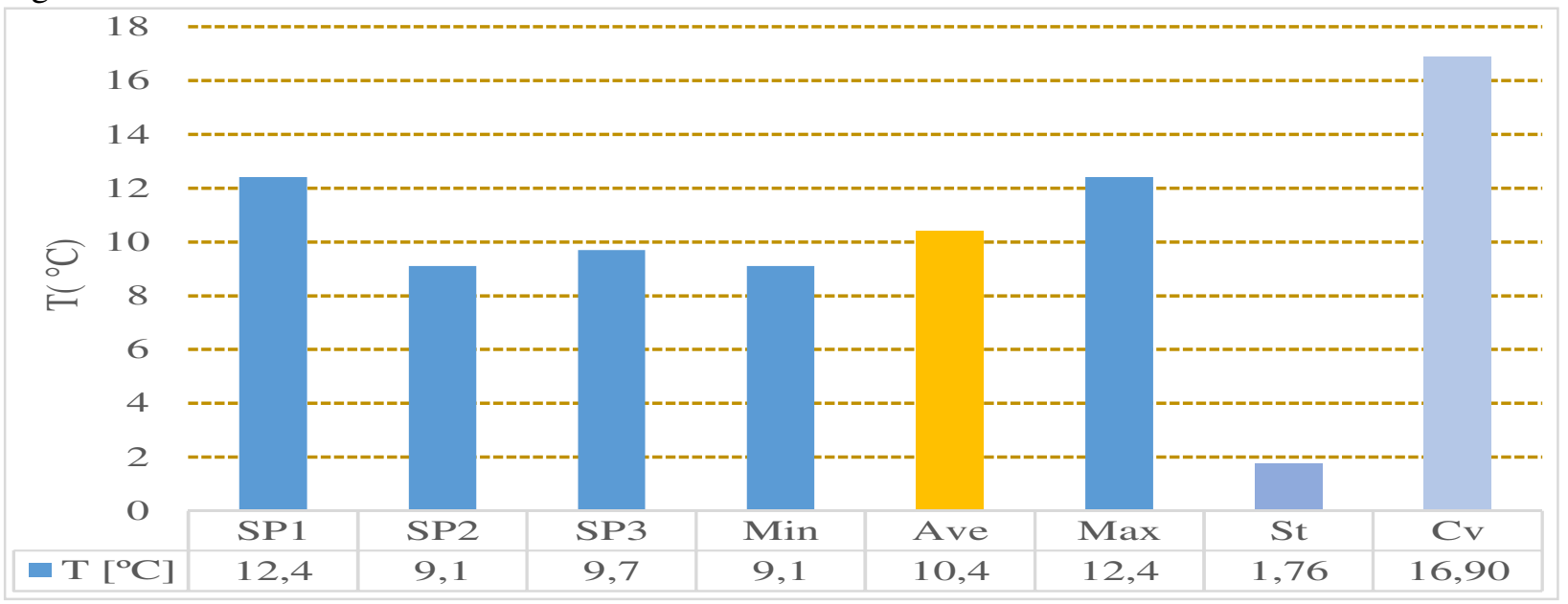

Fig.-2: Temperature variation in the water of Nerodime River

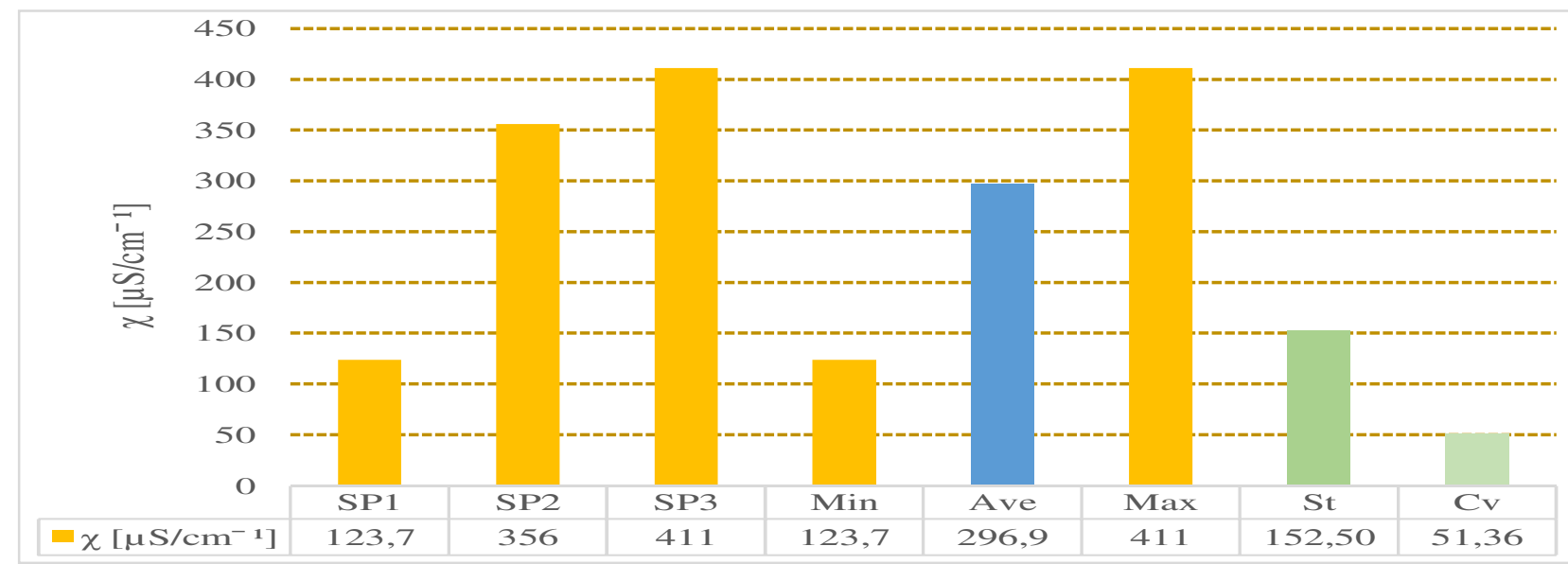

Fig.-3: EC variation in the water of Nerodime River

\section{Dissolved Oxygen(DO)}

Dissolved Oxygen is a highly important quality parameter which determines "the water clarity", because its amount indicates the level of organic and chemical pollution ${ }^{20}$. It is estimated that fish cannot live in waters with dissolved oxygen level below $4 \mathrm{mg} / \mathrm{l}$, while waters with dissolved oxygen level below $2 \mathrm{mg} / \mathrm{l}$ are considered to be highly eutrophic and polluted. The values measured at the three stations of Nerodime River have shown fluctuations of this parameter that ranged from $7.8 \mathrm{mg} / 1$ (SP2 station-Gërlicë) to 9.2 $\mathrm{mg} / \mathrm{l}$ (SP1 station-Jezerc), the average value being $8.6 \mathrm{mg} / \mathrm{l}$. Compared to the standard values (GD161), it results that the water in Nerodime River appears to be in good sanitary condition. The water at SP1-Jezerc belongs to the first class, whereas the water at the two other stations slightly tends toward the second class. The variation of the dissolved oxygen values is shown in Fig.-6.

\section{Chemical Oxygen Demand (COD)}

This parameter is an indicator that explains rapid acid oxidation. COD with $\mathrm{KMnO}_{4}$ indicates the presence of organic compounds in water. Therefore, water containing organic compounds consumes a certain amount of $\mathrm{KMnO}_{4}$ for their oxidation. COD results are generally higher than BOD5 values. The 
BOD values present approximate theoretical amounts of $\mathrm{O}_{2}$ consumption. They depend primarily on the water content. The measured values at the three stations of Nerodime River have shown fluctuations of this parameter from $4.9 \mathrm{mg} / \mathrm{l}$ to $42.5 \mathrm{mg} / \mathrm{l}$. The minimum value was obtained at SP1-Jezerc ( $4.9 \mathrm{mg} / \mathrm{l})$, the maximum value was obtained at SP3-Runjevë $42.5(\mathrm{mg} / \mathrm{l})$, the average value is $27.5 \mathrm{mg} / \mathrm{l}$. Compared to the GD161 standard values, the water of Nerodime River at the SP1 station-Jezerc belongs to the first class, whereas at the two other stations (SP2-Gërlicë and SP3-Runjevë) belongs to the fourth class. Fig.-7 shows the variation of COD values with some statistical parameters.

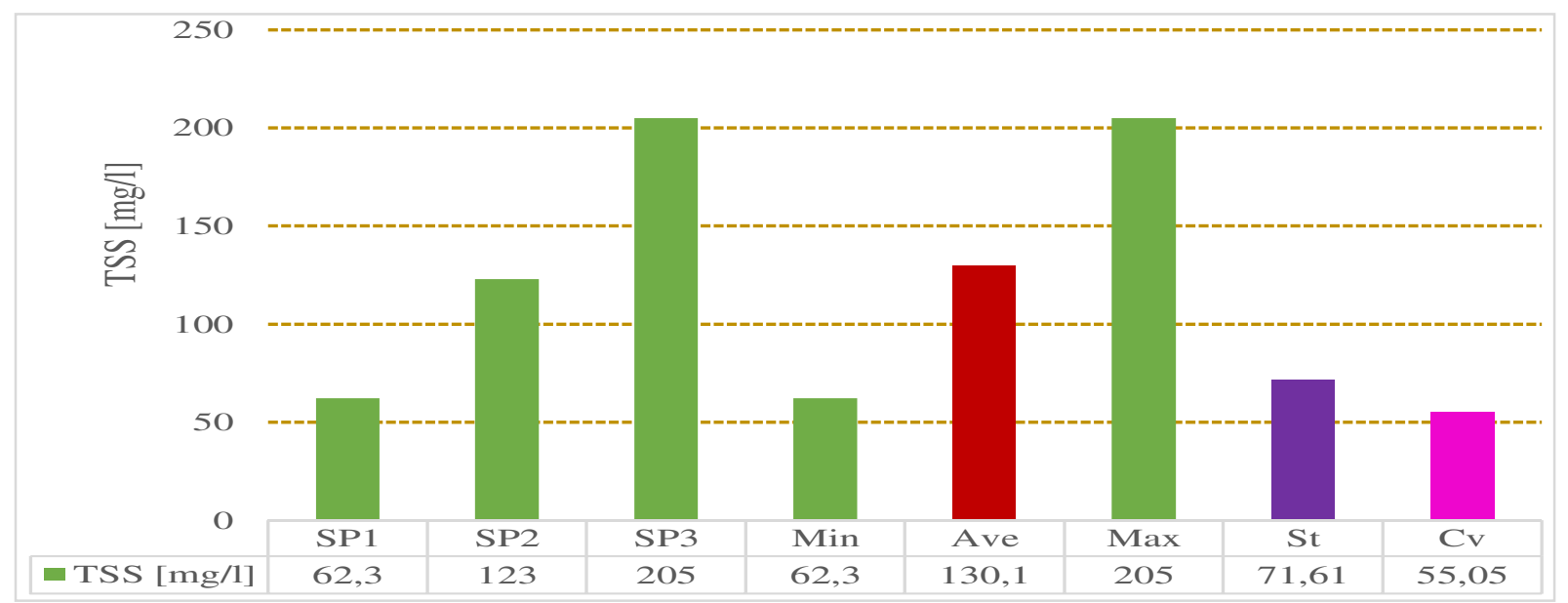

Fig.-4: TSS variation in the water of Nerodime River

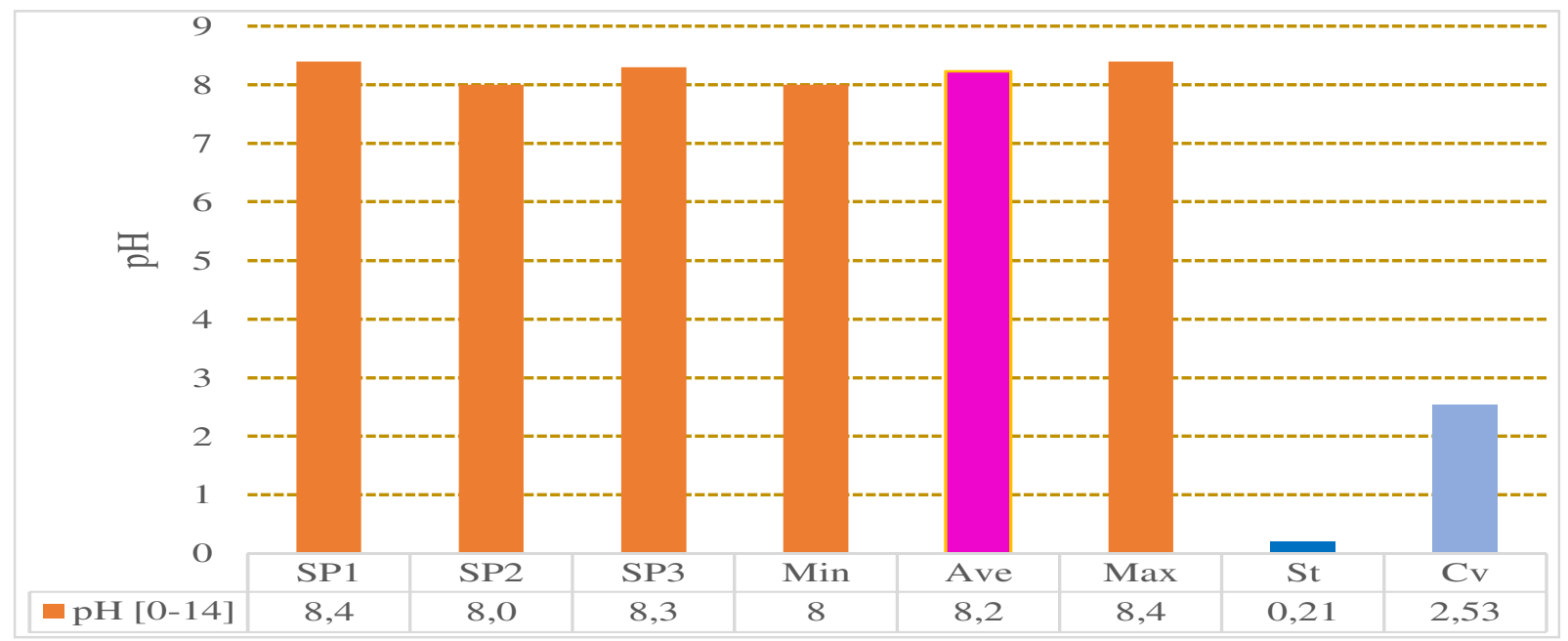

Fig.-5: $\mathrm{pH}$ variation in the water of Nerodime River

\section{Biological Oxygen Demand $\left(\mathrm{BOD}_{5}\right)$}

It is an indicator of the level of organic pollution of water. It indicates the amount of oxygen consumed in 5 days based on the sample and the Total Oxygen Demand (TOD), namely the amount of oxygen consumed in 30 days based on the sample. The greater the biological demand for oxygen, the greater the amount of biologically degradable substances, consequently the higher the level of organic pollution. The measured values at the three stations of Nerodime River have indicated the following: the minimum value of $2.3 \mathrm{mg} / \mathrm{l}$ was obtained at SP1 station-Jezerc, the maximum value of $19.0 \mathrm{mg} / \mathrm{l}$ was obtained at SP3 station-Runjevë, the average value is $12.4 \mathrm{mg} / \mathrm{l}$. The values obtained for $\mathrm{BOD}_{5}$, compared to the GD161 standard values, show that in terms of water quality the water of Nerodime River at SP1 station-Jezerc 
belongs to the first class, whereas in the other two stations (SP2-Gërlicë and SP3-Runjevë) belongs to the fourth class. The variation of $\mathrm{BOD}_{5}$ values is shown in Fig.-8.

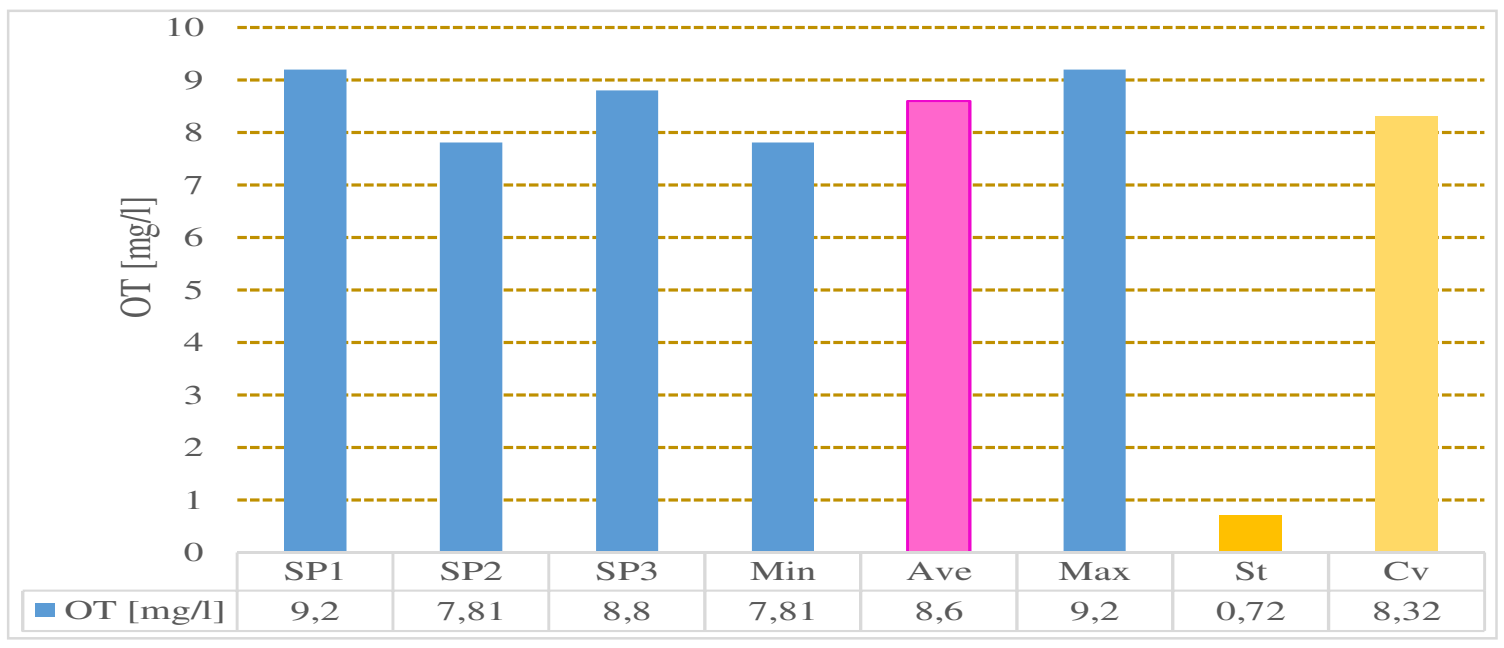

Fig.-6: Dissolved Oxygen (DO) variation in the water of Nerodime River

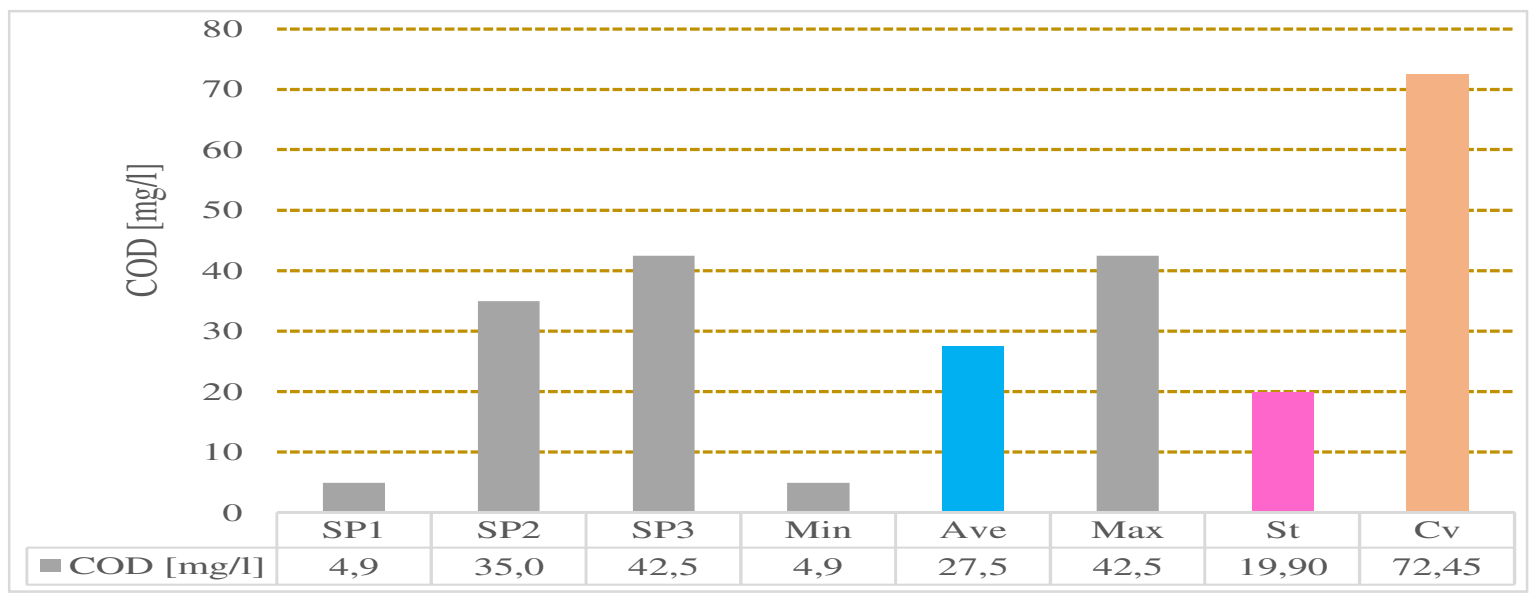

Fig.-7: COD variation in the water of Nerodime River

\section{Nitrates $\mathrm{NO}_{3}^{-}$}

It constitutes a higher degree of oxidation of the nitrogen in nature. Drinking water must not contain more than $15 \mathrm{mg} / \mathrm{dm}^{3}$ of nitrate as nitrogen. In surface waters they are present in small quantities, whereas in groundwater they are found in larger quantities. Nitrates present the final product of biological oxidation of organic pollution. This indicates that the water was polluted in the past. In the water of Nerodime River, the measured values for nitrate showed variation as in Fig.-9. The minimum value was $0.15 \mathrm{mg} / \mathrm{l}$ (SP1-Jezerc), the maximum value was $4.8 \mathrm{mg} / \mathrm{l}$ (SP3-Runjevë), the average value is $2.4 \mathrm{mg} / \mathrm{l}$. Compared to the Romanian standard for assessing the ecological status of surface waters (GD161), it results that at SP1 station the water of Nerodime River belongs to the first class, at SP2 station the water tends to belong to the second class, and at SP3 station the obtained value is close to the water quality of the third class. Given this, it can be said that the deterioration of water quality indicates a downward trend at the stream bottom as far as this parameter is concerned.

\section{Nitrites $\mathrm{NO}_{2}^{-}[\mathrm{mg} / \mathrm{l}]$}

Nitrates are toxic and the maximal acceptable amount in drinking water is $0.005 \mathrm{mg} / \mathrm{dm}^{3}$ of nitrite as nitrogen. They are formed by the dissolution of biological and industrial pollution. The obtained results at the sampling stations of Nerodime River have shown the following values: at SP1 station-Jezerc, there 
were no nitrites, whereas at the two other stations in Gërlicë and Runjevë the following values were shown: SP2-Gërlicë $0.091 \mathrm{mg} / \mathrm{l}$ and SP3-Runjevë $0.381 \mathrm{mg} / \mathrm{l}$. Compared to the standard values (GD161), the obtained values at these two stations are within the normal range thus ranking the water in the third class (SP2), and in the fifth class (SP3) respectively. The variation of the values for $\mathrm{NO}_{2}$ - is shown in Fig.-10.

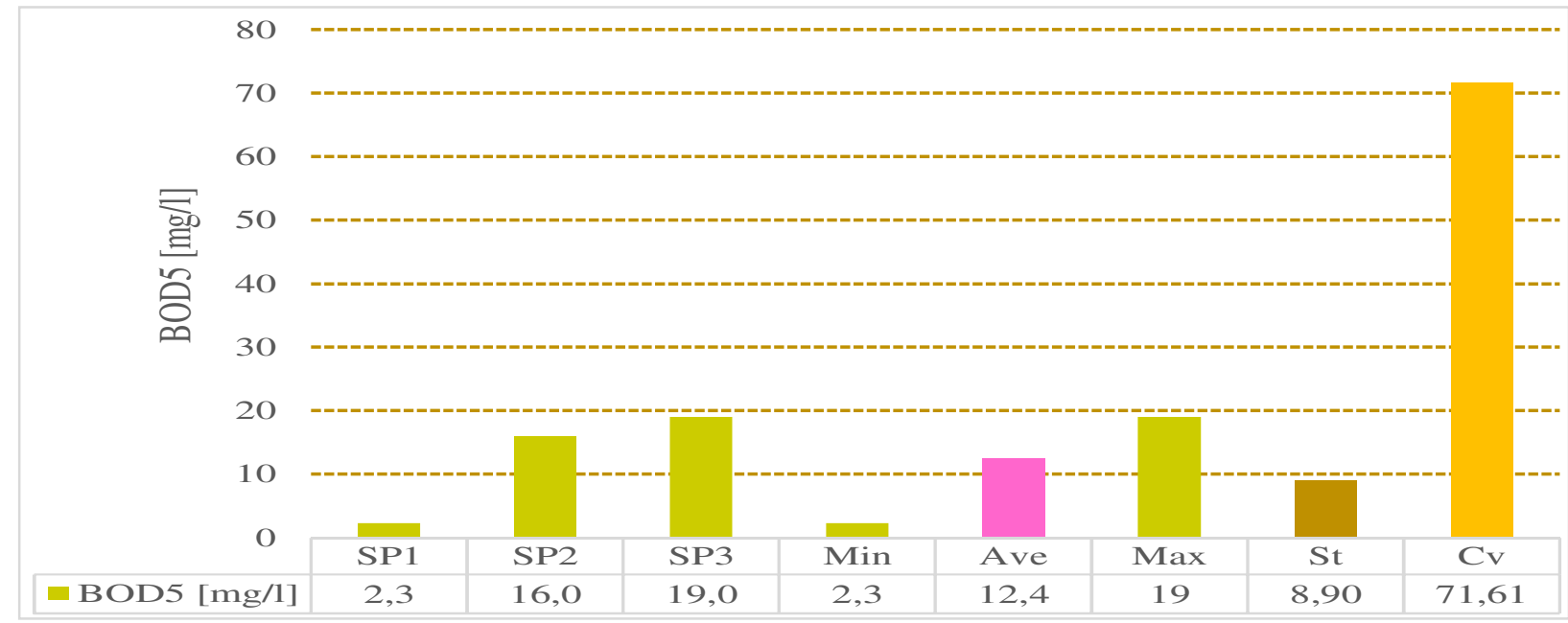

Fig.-8: $\mathrm{BOD}_{5}$ variation in the water of Nerodime River

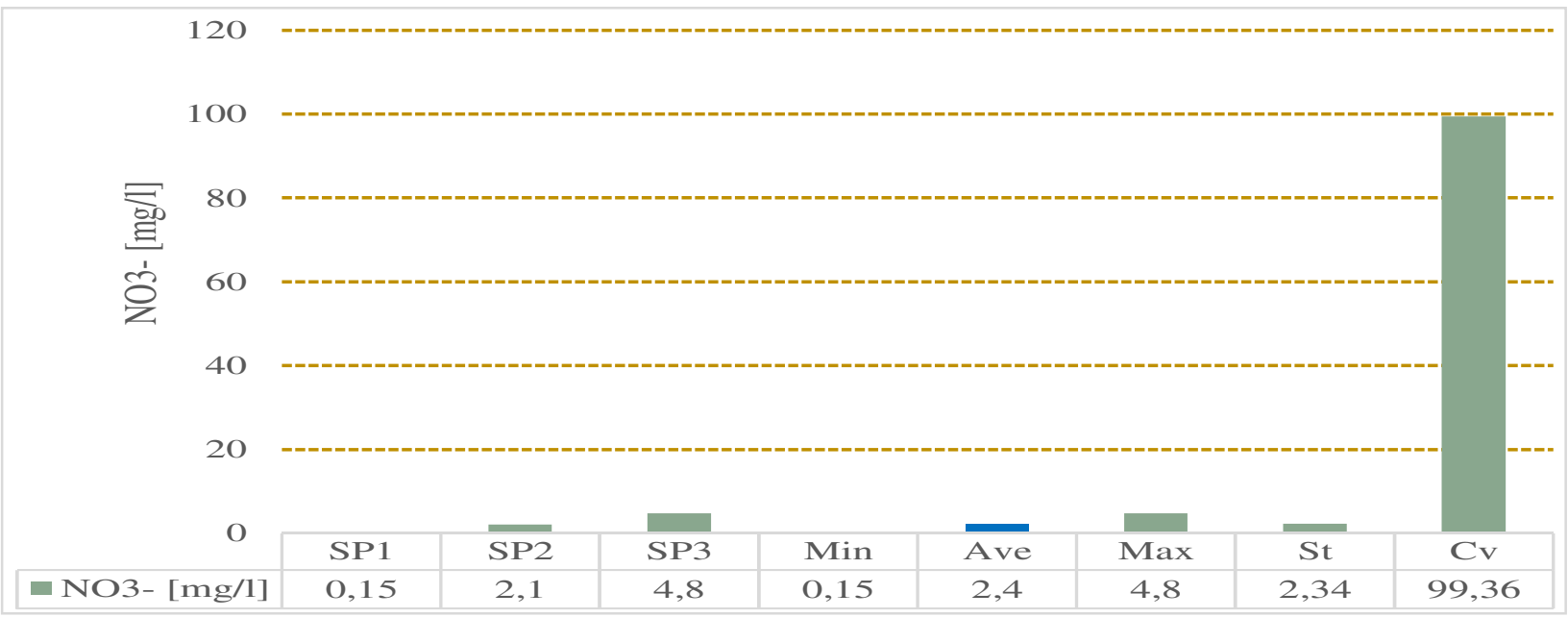

Fig.-9: $\mathrm{NO}_{3}{ }^{-}$variation in the water of Nerodime River

\section{Ammonium $\mathrm{NH}_{4}{ }^{+}[\mathrm{mg} / \mathrm{l}]$}

Ammonium is present in many surface glasses of water and groundwater. As such product, it results from the microbiological activity of the dissolution of organic compounds of nitrogen. Its presence in the water is indicative of a new organic pollution. The ammonia risk in water depends on temperature, $\mathrm{pH}$ value, oxygen and dissolved carbon dioxide. The monitoring and analysis of this parameter in the water of Nerodime River have shown a value of $5.84 \mathrm{mg} / \mathrm{l}$ (SP2-Gërlicë) and $6.9 \mathrm{mg} / \mathrm{l}$ (SP3- Runjevë). Compared to Romanian standard values for assessing the ecological status of surface waters (GD161), it results that the obtained values exceed the normal range, thus ranking the water of Nerodime river in the fifth class (ie, the obtained values of two stations exceed the standard value $>3.2 \mathrm{mg} / \mathrm{l}$ ). The variation of $\mathrm{NH}_{4}{ }^{+}$ values is shown in Fig.-11. 
RASĀYAN J. Chem.

Vol. 11 | No. 2 |554 - 568 | April - June | 2018

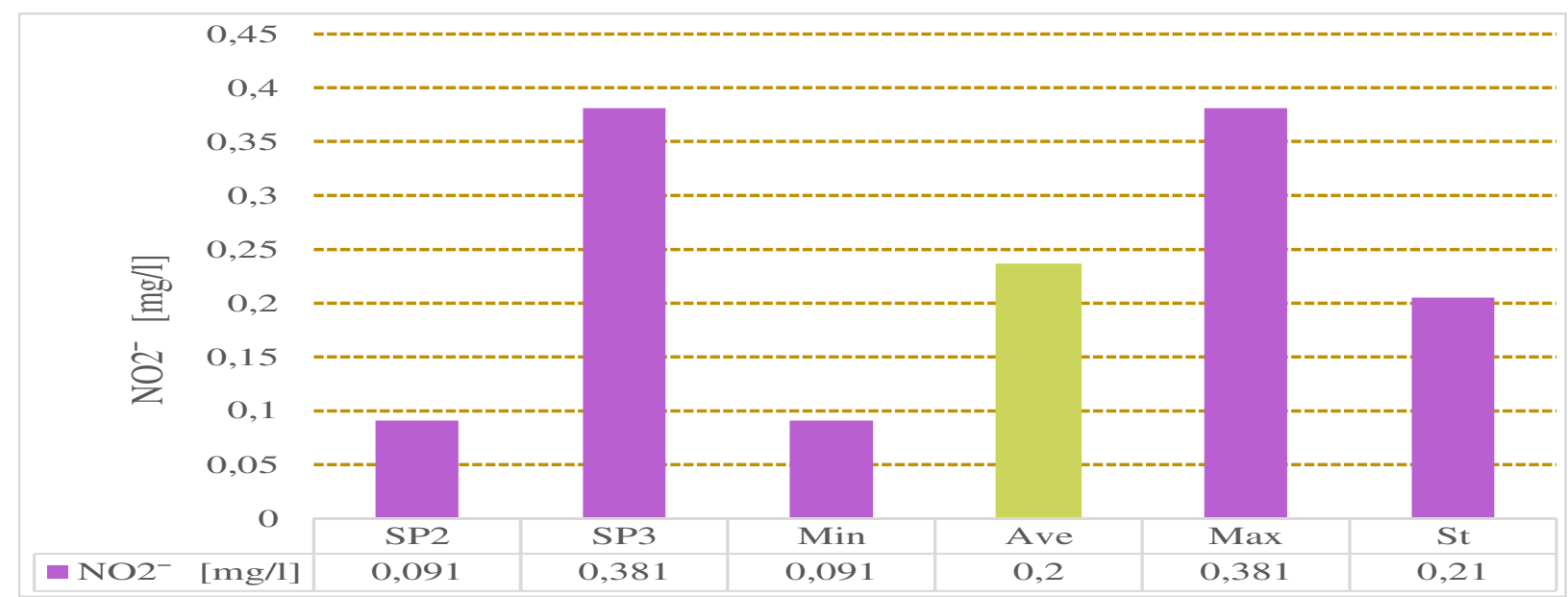

Fig.-10: $\mathrm{NO}_{2}^{-}$variation in the water of Nerodime River

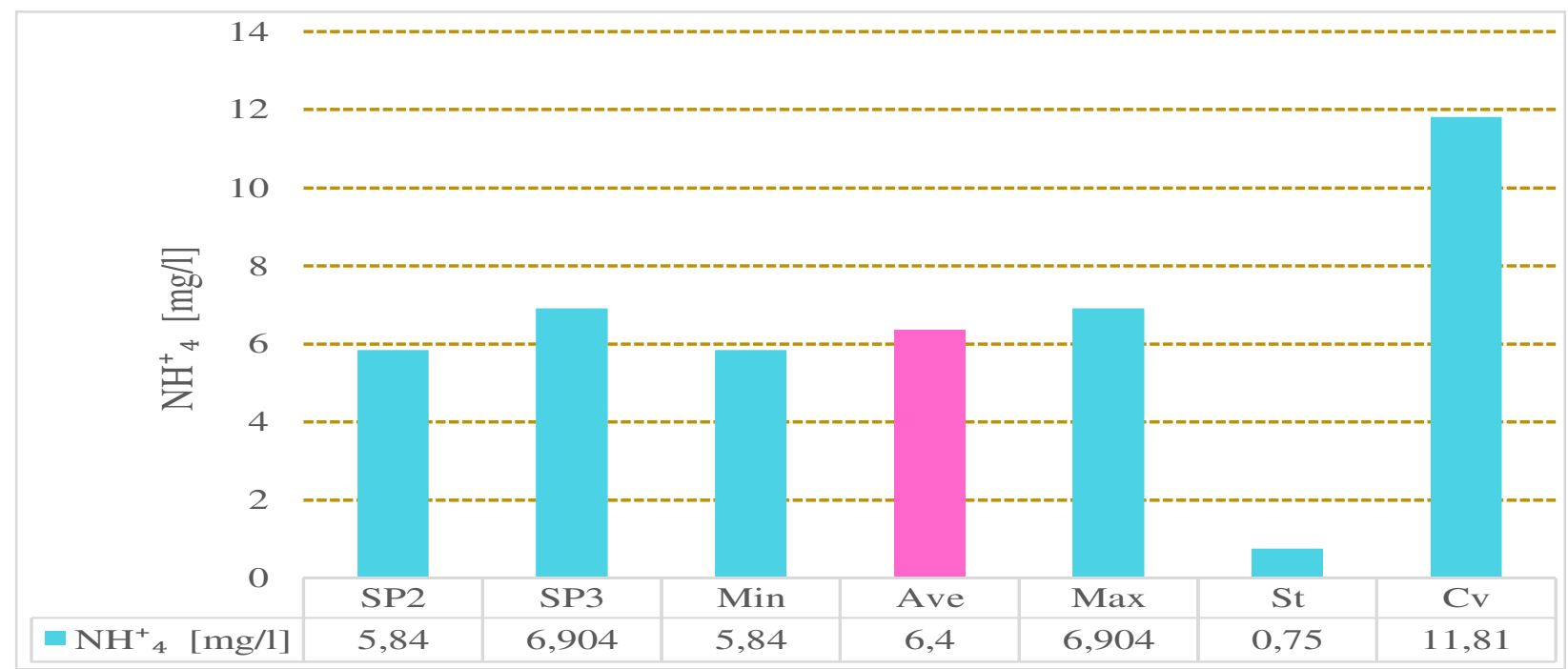

Fig.-11: $\mathrm{NH}_{4}{ }^{+}$variation in the water of Nerodime River

\section{Sulfates $\mathrm{SO}_{4}{ }^{2-}[\mathrm{mg} / \mathrm{l}]$}

Sulfates are widely distributed in nature and their amount in natural waters varies. In the group of other indicators of pollution worth mentioning are the sulfur compounds, which, according to the oxygenreduced reaction, are represented by sulfates, sulfites and sulfur. Sulfites pose a concern to water bodies in that they provoke anaerobic phenomena during their transformation into sulfate by consuming water oxygen. This indicator in the water of Nerodime River at the two stations SP2-Gërlicë and SP3-Runjevë has shown a value of $8.0 \mathrm{mg} / \mathrm{l}$ and $11.0 \mathrm{mg} / \mathrm{l}$ respectively. The obtained values at these two stations were within Romanian standard for assessing the ecological status of surface waters (GD161).

\section{Chlorine $\mathrm{Cl}^{-}[\mathrm{mg} / \mathrm{l}]$}

Although it has a low distribution in the atmosphere, it is widely found in water, often in large concentrations. The chlorine values obtained at the three stations of Nerodime River show values from $2.84 \mathrm{mg} / \mathrm{l}$ to $9.94 \mathrm{mg} / \mathrm{l}$. The minimum value of $2.84 \mathrm{mg} / \mathrm{l}$ was obtained at the SP1 station-Jezerc, whereas the maximum value was obtained at SP3 station-Runjevë, the average value is $6.2 \mathrm{mg} / \mathrm{l}$. Compared to the Romanian standard for assessing the ecological status of surface waters (GD161), it results that the obtained values for $\mathrm{Cl}^{-}$, at all measuring stations are within the normal range and that the water of Nerodime river is ranked in the first class. 


\section{Phosphate ions}

With regard to the phosphate ion analyzed at three stations during the spring season, the highest values were obtained at SP2-Gërlicë station $(0.5 \mathrm{mg} / \mathrm{l})$, whereas the lowest values were obtained at SP3-Runjevë station $(0.05 \mathrm{mg} / \mathrm{l})$; at SP1-Jezerc station the values were below the referred values $(<0.02)$, thus the average value was $0.214 \mathrm{mg} / \mathrm{l}$. According to the ecological status of surface waters (GD161), at SP3Runjevë station the water belongs to the second (II)class, whereas at SP2-Gërlicë station the water belongs to the fifth class.

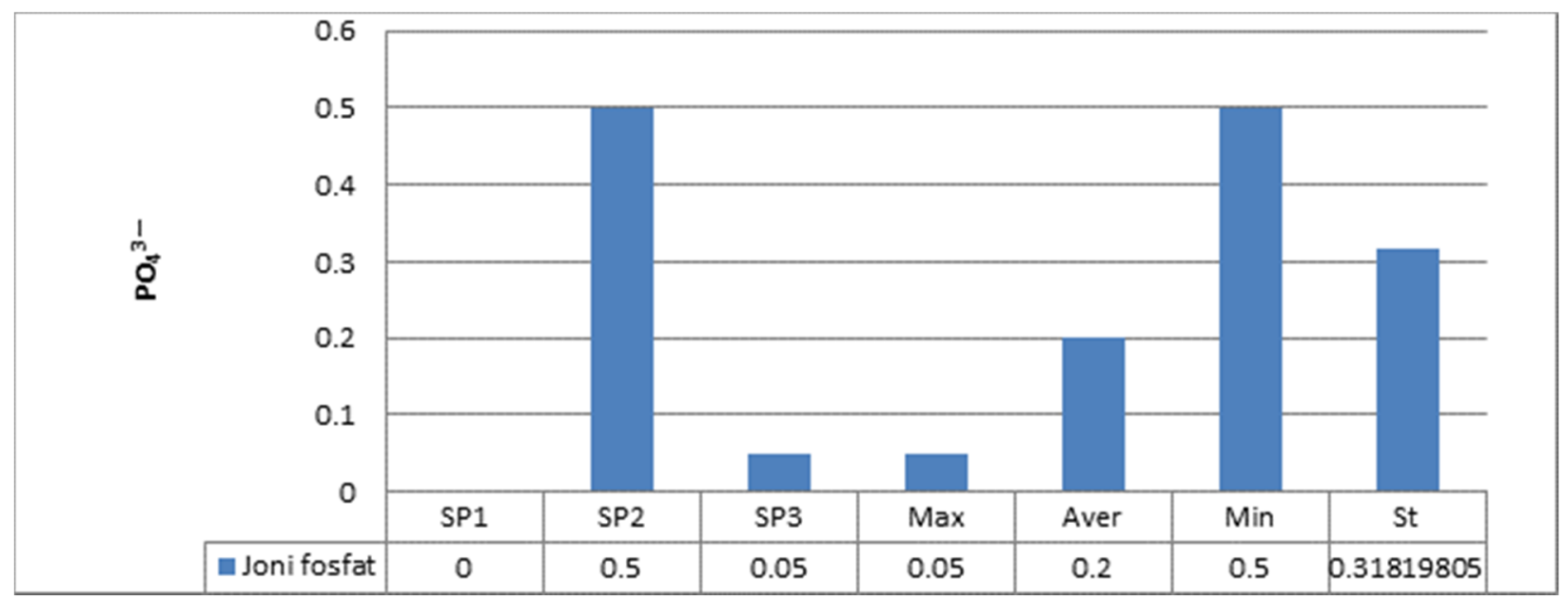

Fig.-12: $\mathrm{PO}_{4}{ }^{3-}$ variation in the water of Nerodime River

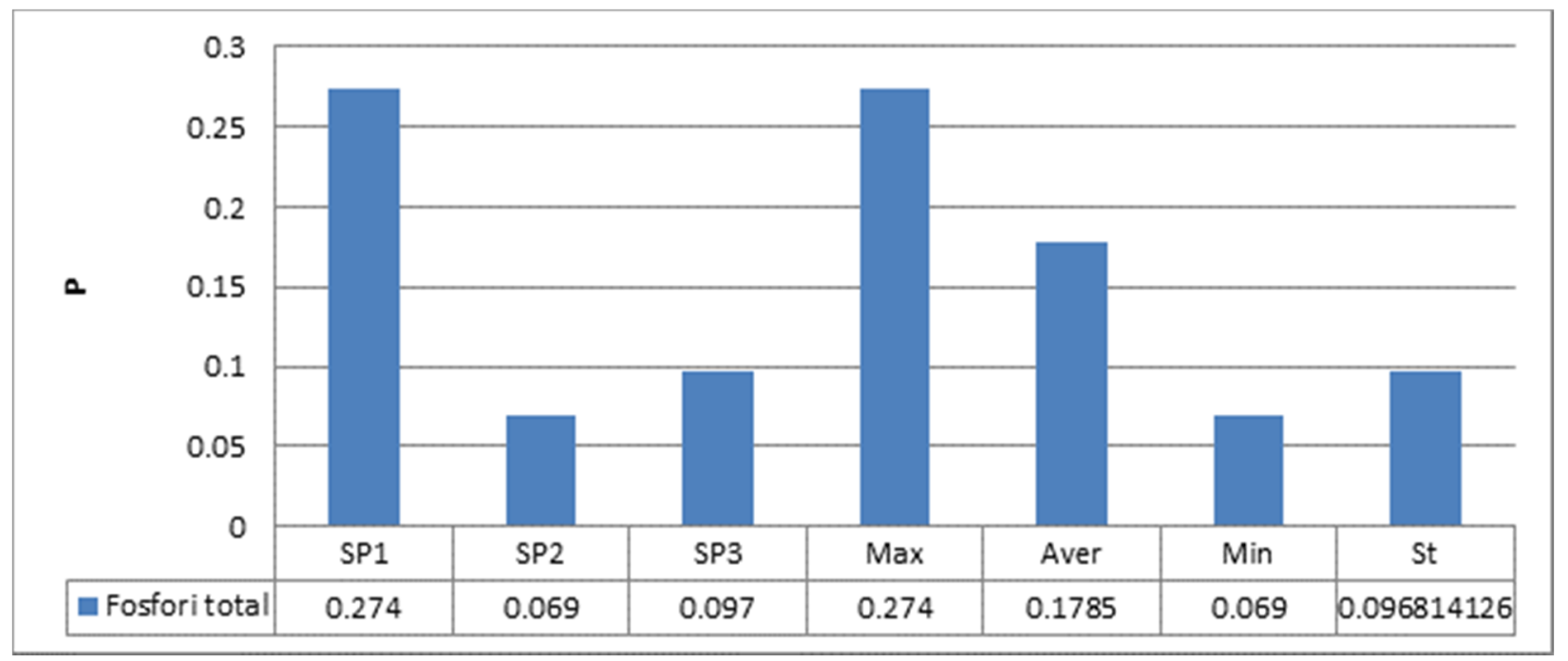

Fig.-13: Total Phosphate- variation in the water of Nerodime River

\section{Total Phosphate}

Phosphate is an essential element for animal growth and can be a nutrient that limits the primary productivity of aquatic organisms. Based on the analysis at the three stations during the spring season, the maximum value was $0.274 \mathrm{mg} / \mathrm{l}$ at SP1-Jezerc, the minimum value was $0.069 \mathrm{mg} / \mathrm{l}$ at SP2-Gërlicë, thus the average value is $0.17 \mathrm{mg} / \mathrm{l}$. According to the ecological status of surface waters (GD161) at SP1Jezerc station the water belongs to the second (II) class, whereas at SP3-Runjevë station and SP2-Gërlicë station the water belongs to the first (I) class.

Water quality assessment based on Macroinvertebrate Biotic indices

The composition of macroinvertebrates in river Nerodime in the spring season is presented in Table-2. 
RASĀYAN $J$. Chem.

Vol. 11 | No. 2 |554 - 568 | April - June | 2018

Table- 2: Macroinvertebrate diversity along the river Nerodime.

\begin{tabular}{l|c|c|c}
\hline Macroinvertebrates & SP1 & SP2 & SP3 \\
\hline Diptera & & & \\
\hline Blephariceridae & + & & \\
\hline Athericidae & + & & \\
\hline Tipulidae & + & & \\
\hline Plecoptera & + & & \\
\hline Perlodidae & + & & \\
\hline Perloidae & + & & \\
\hline Ephemeroptera & + & & \\
\hline Heptagenidae & & & \\
\hline Baetidae & + & & + \\
\hline Trichoptera & & & \\
\hline Rhyacophilidae & & + & + \\
\hline Isopoda & & & \\
\hline Asellidae & & & \\
\hline Oligochaeta & & & \\
\hline Hirudinea & & & \\
\hline Erpobdellidae & & & \\
\hline Number of taxa/families & 8 & & \\
\hline
\end{tabular}

Taxa Richness (TR) indicates the health of the community through its' diversity and increases with increasing habitat diversity, suitability, and water quality. TR equals the total number of taxa represented within the sample. The healthier the community is, the greater the number of taxa found within that community $^{21}$. As shown in Table 2,during our investigation 11 macroinvertebrate taxa were recorded, which belong to three animal groups: Insecta, Crustacea and Annelidae. Class Insecta was the most dominant group among the macroinvertebrates, represented with 4 orders, respectively with 8 families, that consists about $72,7 \%$ of the total number.Crustacea were presented with a single order Isopoda, respectively family Assellidae consisting 9,09\% of macroinvertebrates and Annelidae with two classes: Oligochaeta and Hirudinea, consist the remaining $18.18 \%$. The richest among insect group was Diptera presented with 3 families, followed by Plecoptera and Ephemeroptera with two families each. Other groups:Trichoptera, Isopoda and Hirudinea were less presented, with only one recorded family each.In terms of sampling stations, the richest was SP1-Jezerci, with 8 macroinvertebrate taxa, SP2 was completely dominated by a single group, and SP3 is represented with 3 taxa.

Shannon-Wiener, Mergalef and Menhinick diversity indices showed the highest diversity values at the station SP1, in the source area of the river, whereas the lowest value was registered in station 2, in the middle stream. Low degree in taxonomic richness and diversity in the spring season for all three sites were confirmed in the values of BMW index. The BMWP score values varied from 64 in station SP1 to 1 in station SP2. The same trend has shown the ASPT value, with the highest score upstream in SP1-Jezerc, and the lowest in station SP2-Gerlice.SWRC Biotic Index is based on tolerance values of the present macroinvertebrate families in the sample ${ }^{22}$. In our study, SWRC has shown the lowest value in station 1Jezerc, whereas the highest value was registered in station SP2.

EPT index is calculated as a sum of Ephemeroptera + Plecoptera + Trichoptera species richness's ${ }^{23}$. The highest value of EPT is registered in station 1 with 5 EPT families present, whereas the lowest was in station 3, where only 1 EPT family is recorded. At station 2 EPT where not present at all. Family Biotic index is calculated based on the tolerance values of macroinvertebrate families to various levels of dissolved oxygen ${ }^{24}$. The lowest FBI value, which indicates higher water quality, was registered in station one- SP1, whereas the highest value was in station 3. The values of biotic indices and water quality classes are shown in Table-3.

In our study water quality of River Nerodime was examined in three stations in light of physicochemical parameters and biotic indices. In regard to physicochemical parameters, the water in 3 stations showed 
variable quality (Table-1). Temperature and $\mathrm{pH}$ showed only a slight variation in three stations and were within a normal range.(Fig.-1 and 4), whereas Electrical conductivity $\chi\left[\mu \mathrm{S} / \mathrm{cm}^{-1}\right]$ and Total suspended solid have shown an increased level downstream the river. EC is an excellent indicator of total dissolved solids which is a measure of salinity which affects the taste of potable water ${ }^{25}$ Dissolved oxygen is necessary to many forms of life including fish, invertebrates, bacteria, and plants. Compared to the standard values (GD161), it results that the water in Nerodime River appears to be in good sanitary condition. The water at SP1-Jezerc belongs to the first class, whereas the water at the two other stations slightly tends toward the second class. The relatively good saturation with oxygen in SP2 and SP3, despite the discharge of many pollutants, can be justified with the high water level in the period of sampling, due to snow melting in mountain areas.

Table-3: Macroinvertebrate biotic indices values and Water quality classes

\begin{tabular}{|c|c|c|c|}
\hline & $S P 1$ & $S P 2$ & $S P 3$ \\
\hline $\mathrm{Nr}$ of taxa-Taxa Richness & 8 & 1 & 3 \\
\hline Abundance & 74 & 961 & 167 \\
\hline Shannon Wiener-diversity index -H & 1.59 & 0 & 0.58 \\
\hline Mergalef diversity index & 1.85 & 0 & 0.39 \\
\hline Menhinick index & 1.046 & 0.032 & 0.23 \\
\hline BMWP & 64 & 1 & 10 \\
\hline Quality Class & High-Class II & $\begin{array}{c}\text { Poor } \\
\text { Class IV }\end{array}$ & $\begin{array}{c}\text { Poor } \\
\text { Class IV }\end{array}$ \\
\hline ASPT & 8 & 1 & 3.33 \\
\hline Quality Class & $\begin{array}{l}\text { Clean } \\
\text { Class I }\end{array}$ & $\begin{array}{c}\text { With impact-severe } \\
\text { pollution } \\
\text { Class IV }\end{array}$ & $\begin{array}{l}\text { With impact - } \\
\text { severe pollution } \\
\text { Class IV }\end{array}$ \\
\hline SWRC -BI & 4.95 & 8 & 7.95 \\
\hline Quality Class & $\begin{array}{c}\text { Good } \\
\text { Class II }\end{array}$ & $\begin{array}{c}\text { Poor } \\
\text { Class IV }\end{array}$ & $\begin{array}{c}\text { Poor } \\
\text { Class IV }\end{array}$ \\
\hline EPT index & 5 & 0 & 1 \\
\hline Quality Class & $\begin{array}{c}\text { Clean } \\
\text { Class III }\end{array}$ & $\begin{array}{c}\text { Poor } \\
\text { Class IV }\end{array}$ & $\begin{array}{c}\text { Poor } \\
\text { Class IV }\end{array}$ \\
\hline FBI & 0.36 & 8.0 & 8.56 \\
\hline Quality Class & $\begin{array}{c}\text { Excellent } \\
\text { Class I }\end{array}$ & $\begin{array}{c}\text { Poor } \\
\text { Class IV }\end{array}$ & $\begin{array}{c}\text { Very poor } \\
\text { Class V }\end{array}$ \\
\hline
\end{tabular}

A significant increase of $\mathrm{COD}, \mathrm{BOD}_{5}$ as well as nitrites, nitrates and ammonium in sampling sites 2 and 3 , indicate for environmental degradation in these two stations due to the presence of organic matter originating from municipal wastewaters, industry and agricultural runoff. Those, the values of abovementioned variables (Fig. 2-13) classify the water in SP1 in the first class of quality (GD161), whereas SP2 and SP3 belong to the class three and four, respectively five. It is believed that the same pollution sources are the primary cause of the changes in diversity and the abundance of benthic macroinvertebrates at the sampling sites. Based on the taxa richness, diversity index of Shannon-Wiener $\left(\mathrm{H}^{\prime}\right)$, Mergalef and Menhinick, BMWP, ASPT, FBI, HBI and EPT(Table-3) water in 3 stations showed variable quality. In regard to taxa richness and diversity, we can conclude that the benthic fauna in river Nerodime in spring was relatively modest. According to Wilhm and Dorris (1966)and Mason (2002), if the Shanon-Wiener diversity index has the value $1-3$, it indicates moderate pollution ${ }^{26}$.

In total 1202 macroinvertebrate specimen were collected during our research in river Nerodime. These specimen in taxonomic terms belong to three groups: Insecta, Crustacea and Annelidae.In SP1-Jezerc, upstream of the river, in total 8 taxa were registered, dominated by Diptera, with three families, followed by Plecoptera and Ephemeroptera with two families each, and Trichoptera with a family. However, it 
should be stated that the period of sampling in spring season was characterized by high water regime and high water current, two of the most important characteristics in running waters that could have impacted the benthic fauna. In relation to this, most of the presented macroinvertebrate taxa in SP1 are species that have developed adaptations to living in current with high velocity, such as flattening body in Plecoptera and some Ephemeroptera-Heptagenidae, or ventral suckers in Blepharicidae ${ }^{27}$. Regarding the sensitivity of taxa to pollution, most of the macroinvertebrates recorded in SP1 are sensitive to pollution, with a tolerance index ranging from 0 (Blepharicidae), to 4 (Baetidae and Heptageinade) ${ }^{28-30}$. The values of Biotic indices show a deviation in the classification of water quality categories in SP1.

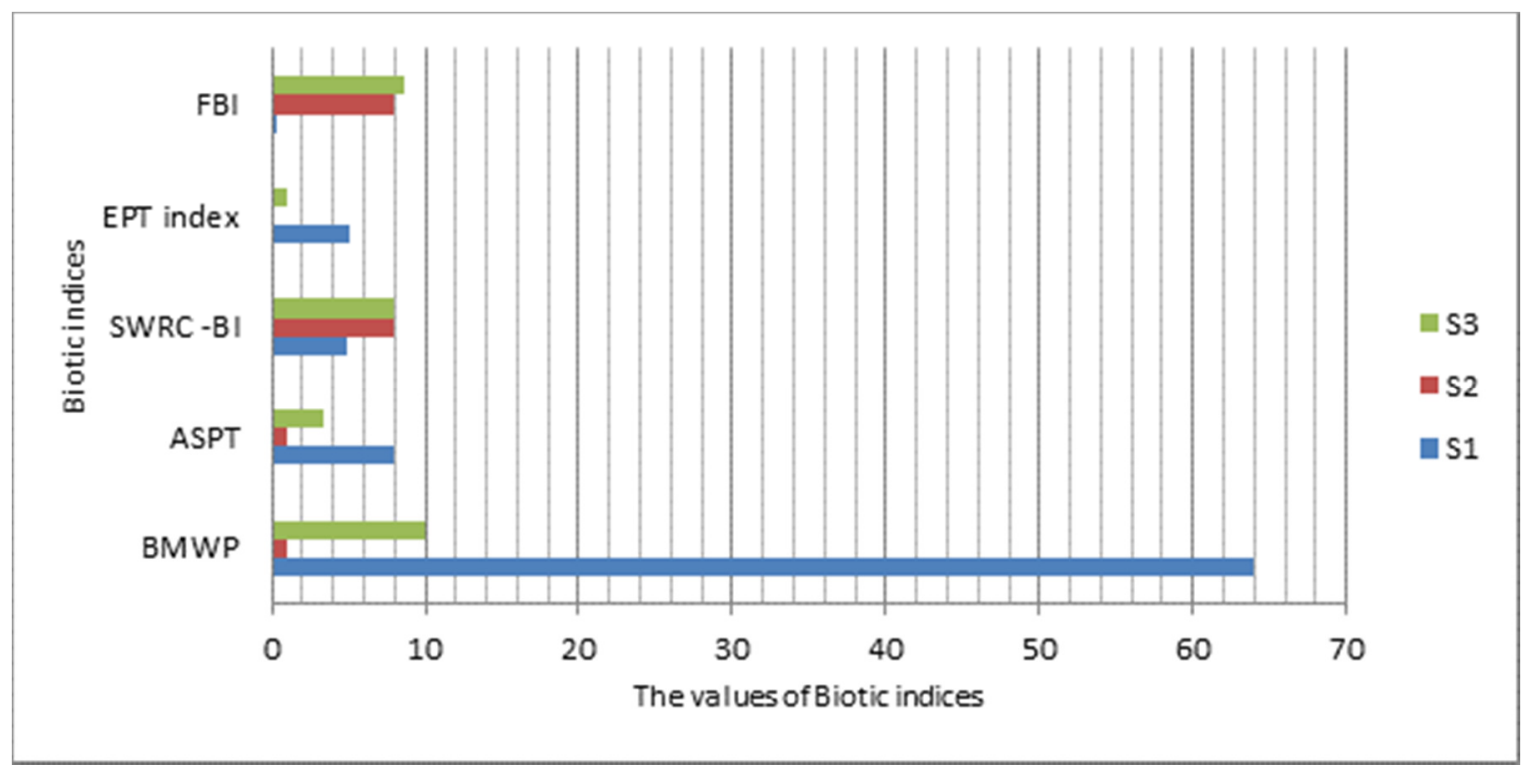

Fig.-14: The values of Biotic indices

Based on SWRC, BMWP and EPT values, the water in SP1 belongs to good and moderate quality, whereas ASPT and FBI classify this station as clean and excellent. Going downstream the river, a number of macroinvertebrate taxa significantly decreases as the result the of environmental changes caused by many pollution sources coming from urban settlements in Ferizaj, that considerably exacerbate the state of the river. This condition is also reflected in the physical parameters of water, such as odor, color, and water-soluble matter, but also in the composition of the animal groups. In this station in middle stream of the river, only representatives of Oligochaeta were present, which are organisms of high tolerance to organic pollution. The EPT taxa were not present in this station, even though some Trichopera families are semi-sensitive to pollution and are mostly part of macroinvertebrate community in lowland parts of the river. It is a well-known fact that pollution of a stream reduces the number of sensitive species of the system while frequently creating an environment that is favorable to a few species (i.e., pollution-tolerant forms $)^{31}$. Thus, in a polluted stream, there are usually large numbers of a few species, while in a clean stream there are moderate numbers of many species. These species can tolerate low oxygen water because they breathe atmospheric oxygen via snorkel-like breathing tubes (i.e., the rat-tailed maggot) or have some other special adaptations like respiratory pigments which enable them to more efficiently obtain oxygen that is in low concentration (i.e., Tubifex worms and chironomid midge larvae). In our research it revels that in heavy polluted streams the number of taxa is low but the abundance is very high. In SP2 Gerlice, diversity was reduced only to Oligochaeta, but the abundance was very high and consisted of 961 specimens in a $\mathrm{m}^{2}$. Both physicochemical variables and Biotic indices showed low values in this station and qualify water as poor quality.A similar situation is also present in the third locality in Runjeve-SP3, in the municipality of Kaçanik, which situation is evidenced by the massive death of fish during the sampling period. A significant increase of some of the physicochemical; parameters e.g., 
conductivity, total suspended solids, COD, BOD5, and Ammonium, indicates the changes in nutrient content in the water in this station as the result of the effluent discharge. Macroinvertebrate fauna in this station consisted of 3 taxa: Baetidae, Assellidae and Erpobdellidae, last two are well known as highly tolerant to organic pollution. Like in station 2, in SP3 EPT index is not calculated, due to the lack of Plecoptera and Trichoptera families as sensitive organisms to pollution. All the measured variables (Table-1 and 3) showed the lowest values in this station, caused by anthropogenic sources of pollution such as municipal wastewaters, industrial wastes, animal farming, agriculture runoff, etc. The water in this station is qualified poor and very poor quality.

\section{CONCLUSION}

We concluded that using multimetric analysis a station could be qualified into more than a category of water quality. Those, none of the parts of the river Nerodime is classified in Class I of water quality. In sampling station SP1-Jezerci, in the source area, the water quality is qualified Excellent, Good and Moderate, indicating the presence of pollution even in this part of the river. From the results obtained in our research, we can conclude that the state of Nerodime River in the middle-SP2 and downstream-SP3, is very severe, almost alarming, as a result of heavy pollution, especially that of organic matter. Treatment of wastewaters from the municipalities as well as industrial waters before being discharged into rivers and preventing the degradation of the riverbed from various activities would be the appropriate measures to be taken to remedy this condition. We can conclude that the use of Biological quality elements, apart from Physicochemical elements, is a useful tool for Monitoring of river ecosystems in the country.

\section{REFERENCES}

1. The Water Framework Directive (2000/60/EC),(2000).

2. N. De Pauw, P.F Ghetti, P. Manzini, and P. Spaggiari, 1992, Biological assessment methods for running water, Commission of the European Communities, Brussels, Belgium, pp.217-248

3. D. M. Rosenberg, and V. H. Resh, The use of artificial substrates in the study of freshwater macroinvertebrates, Artificial Substrates, Cairns, J. (Ed.) Ann Arbor Science: Ann Arbor, MI, USA. p. 175, 235 (1982).

4. J.L. Metcalfe-Smith, Biological water quality assessment of rivers: use of macroinvertebrate communities', Blackwell Scientific Publications: Oxford, UK.p. 144, 170 (1994).

5. D. Hering, O. Moog, L. Sandin and P. Verdonschot, Hydrobiologia, 516(1-3), 1 (2004).

6. J. Illies, Int. Revue. Ges. Hydrobiol., 46(2), 205, (1961), DOI: 10.1002/iroh.19610460205

7. J. Jr. Cairns and Pratt R.J, 1993, A History of Biological Monitoring Using Benthic Macroinvertebrates. In: Rosenberg, D.M. and Resh, V.H., Eds., Freshwater Biomonitoring and Benthic Macroinvertebrates, Chapman/Hall, New York, pp.10-27.

8. M.T. Barbour, J. Gerritsen, B.D. Snyder, and J.B. Stribling, Rapid Bioassessment Protocols for Use in Streams and Wadeable Rivers: Periphyton, Benthic Macroinvertebrates and Fish, Second Edition. EPA 841-B-99 -002. U.S. Environmental Protection Agency; Office of Water; Washington, D.C.(1999)

9. A. Shukriu, Ph.D. Thesis, Department of Biology, University of Zagreb, Croatia (1979).

10. F. Zhushi Etemi. Ph. D. Thesis, Department of Biology, University"Hasan Prishtina" Prishtina (2005).

11. P.D. Armitage, D. Moss, J.F. Wright and M.T. Furse, Water. Res.,17, 333, (1983).

12. C. Mason, Biology of Freshwater Pollution, Harlow, England ; New York : Prentice Hall, p.387 (2002).

13. P.D. Armitage, D. Moss, J.F. Wright and M.T. Furse, Water. Res. 17: 333, (1983).

14. H.P.Tachet, M. Richoux, M. Bournaud and P. Usseglio-Polatera. Invertébrés d'eau douce systématique, biologie, écologie . CNRS Editions, 588 pp. (2000).

15. H. Dakoli, Hidrogjeologjia, 111, 174 (2007). 
16. H. Cadraku, A. Beqiraj and H. Sahiti, Buletini i Shkencave Gjeologjike-Special Issue, Tiranë, 1, 380 (2014).

17. M.T. Barbour, J. Gerritsen, B.D. Snyder, and J.B. Stribling, Rapid Bioassessment Protocols for Use in Streams and Wadeable Rivers: Periphyton, Benthic Macroinvertebrates and Fish, Second Edition. EPA 841-B-99 -002. U.S. Environmental Protection Agency; Office of Water; Washington, D.C.(1999)

18. McGonigle J., Education: Education: Leaf Packs and Beyond, Spring 2000 Stroud Water Research Center (2000)

19. R. D. Lenat, and D. L. Penrose, Bulletin North American Benthological Society, 13, 305 (1996).

20. W.L. Hilsenhoff,Journal of the North American Benthological Society, 7(1), 65 (1988).

21. D. M. Joshi, N. S. Bhandari, A. Kumar, and N. Agrawal, RASAYAN J. Chem., 2(3) 579 (2009)

22. L.J. Wilhm and T. C. Dorris, Am. Midl. Nat., 76, 427 (1966)

23. H.B.N. Hynes, The ecology of running waters, University of Toronto Press, Toronto, p.555 (1970).

24. R.W. Bode, A.M. Novak and L.E. Abele, Stream Biomonitoring unit Bureau of Monitoring and Assessment Division of Water NYS Department of Environmental Conservation 50 Wolf Road, Albany, NY 12233-3503 p.78 (1991).

25. R.W. Bode, A.M. Novak and L.E. Abele, Quality assurance work plan for biological stream monitoring in New York State. New York State Department of Environmental Conservation, Albany, NY. NYS DEC Tech. Report, p.89 (1996).

26. R.W. Bode, A.M. Novak , L.E. Abele, D.L. Heitzman and A.J. Smith, Quality assurance work plan for biological stream monitoring in New York State. NYS Department of Environmental Conservation, Albany, NY.p.115 (2002).

27. M.C. Zimmerman, Proceedings of the 5th Workshop/Conference of the Association for Biology Laboratory Education (ABLE), p.85, 98 (1993).

[RJC-2087/2018] 